\title{
Reform Study of Colleges and Universities Teaching Management Based on Scholarship of Teaching
}

\author{
Jing-hong Guo \\ Fundermental Courses Department, Suzhou Health College , Suzhou,China \\ deniseguo@163.com
}

\begin{abstract}
It is the core of teaching management in colleges and universities to improve the teaching quality. But currently, there exits a phenomenon of "heavy science, light teaching". Based on scholarship of teaching, this paper firstly expounds the connotation of teaching management. Secondly, the existing main problems of teaching management in colleges and universities are studied. Finally, according to existing problems, several reform strategies of teaching management are put forward from the perspective of scholarship of teaching. It is of great significance to prompt the development of scholarship of teaching and perfect the teaching management system.
\end{abstract}

Keywords: scholarship of teaching; colleges and universities; teaching management; reform research

\section{Introduction}

Higher education has been widely spread in our country, w hich plays an important role in the improvement of national quality and construction of an innovative country. Howeve $r$, with the development of

education situation, college teachers should not only have $h$ igher teaching level, but also should have strong ability of s cientific research. Therefore, higher request

is put forward on teaching management in colleges and univer sities, making it face more severe challenges. At present, th ere exits a phenomenon of "heavy research, light teaching" in colleges and universities, resulting in poor quality of teac hing. Moreover, some contents that teachers give are too in coherent and inconvenient for students to understand, and $\mathrm{s}$ ometimes they even transmit biased ideas to college student $\mathrm{s}$ whose values have not yet fully formed. All the above phe nomenon severely affect the teaching quality and seriously restrict the sustainable development of universities. Therefor $\mathrm{e}$, it is very urgent to deepen the reform of college teaching management work.

Teaching is the premise and foundation of academic rese arch. However, some education workers overthrow the relationship between them, and education work can not get the desired effect. Currently, there are numerous researches on reform of the teaching management, including researche s on implementation and evaluation, teacher performance a ppraisal, the administrative personnel's quality education an d other aspects. From

the perspective of scholarship of teaching, this paper pointe $\mathrm{d}$ out the problems existing in teaching management in coll eges and universities and the proposed several innovative a nd practical reform strategies, hoping to promote the develo pment of education cause in our country.

2. Relevant concepts of teaching management in colleges and universities based on scholarship of teaching

\subsection{Concept of scholarship of teaching}

In the 1990s, the former chairman of the American Carnegie Association for the Teaching Advancement, Ernest Boyer, firstly put forward the concept of "scholarship of teaching" in his special report of "Academic reflection - The focus of the work professor". This report focused on reflecting the declination in quality of undergraduate teaching and narrow teachers evaluation criteria issues and so on. Subsequently, Lee Shulman, R Rice et al made a further expansion of the connotation. Compared with foreign countries, scholarship of teaching theory in China started late. Most Chinese scholars hold the opinion that scholarship of teaching reflects in teachers' professional knowledge, innovation ability, teaching reflection and many other aspects. "Teaching supports academic, and the academic development will be unsustainable without academic".

Through referring to lots of relevant research materials, the connotation of scholarship of teaching can be reflected in the following four aspects: 1) Teachers, the research subject of scholarship of teaching, should have comprehensive knowledge of their professional field, which is the study base of teaching as an academic activity. 2) Teachers need to form a superb professional teaching ability gradually in practice of teaching, which is a necessary formation process of scholarship of teaching. 3) Teachers should be able to creatively teach students how to learn, and it is the purpose of scholarship of teaching. 4) Scholarship of teaching finally forms a systematic and special knowledge system about teaching, and this is the final results of scholarship of teaching. Above all, on the basis of teachers' comprehensive grasp of professional knowledge, scholarship of teaching is a systematic and special academic activity about teaching through constant practice and peer evaluation, forming excellent and professional teaching ability. 


\subsection{Connotation of teaching management in colleges and universities}

Teaching management in colleges and universities is one of the important works of higher teaching, which is a scientific discipline studying the nature, thought, contents, methods, characteristics and regularity of teaching management. It takes teaching as the center, considers a high level of teaching quality as the goal, regards scientific management as the main line, and treats grasping the objective law and internal relations of teaching and its organization management as the measures. In management works of colleges and universities, administration department takes certain management means to achieve established school talent training goal according to the general rule of teaching management. And then we can improve the quality of university professional talent as well as maintain the normal order of teaching. The teaching management discussed in this paper is the organization and management of its own educational work. Its basic tasks mainly include two aspects: 1) exploring the common rule of teaching, and working out characteristic plans in line with the features of teaching management; 2) finding and timely reforming the problems in teaching activities in order to improve the teaching quality of institutions of higher learning and cultivate highquality talents for the country.

Teaching management in colleges and universities has the dual function of administrative management and academic management, playing an important role in the higher school management. Reasonable teaching management method and system is beneficial to improve the level of teaching management in colleges and universities, and ensure the efficient operation of the teaching works. Eventually, it can improve the teaching quality of institutions of higher learning in our country, and promote the development of our country educational work, being of great significance.

\section{Existing problems of colleges and universities teaching management}

In the above, we clear the connotation of scholarship teaching and teaching management in colleges and universities, which provide research foundation for exploring the existing main problems in the teaching management. Through consulting a large number of literature and on-the-spot investigation study, the teaching management in our country exits the following four aspects of problems from the perspective of scholarship of teaching: week consciousness of scholarship of teaching in teaching management, insufficient awareness of teaching quality management, lack of effective evaluation system and lack of sound motivation and restraint mechanics. All these problems restrict the improvement of teaching quality, being the focus of the teaching management reform .

\subsection{Colleges and universities teaching managers' academic concept is weak}

The attitude and philosophy of college teaching managers, the implementer of teaching management reform, have a direct influence on teaching quality. However, theory study of scholarship of teaching in China is still in the preliminary stage, and most studies mainly introduce existing research results in some western countries, resulting in the lack of theoretical guidance for teaching administrators. Moreover, there exists serious perception of "heavy science, light teaching", excluding teaching outside scholarship of teaching. Furthermore, some colleges and universities' teaching management neglects the teaching academic characteristics and laws, and use the same way to manage scholarship of teaching and scholarship of science. As a result, teachers dedicated to teaching and knowledge spreading can't get reasonable evaluation, and they will lose enthusiasm. At last, the quality of education in colleges and universities will be declined, violating the education's essence of cultivating high quality talent.

\subsection{Teaching quality awareness is not enough}

Insufficient consciousness of teaching quality is an important problem of the teaching management in colleges and universities, mainly reflected in the following two aspects: from the angle of the school, the school don't realize the importance of the teaching quality. The vast majority of colleges and universities usually measure teachers through scientific research and academic achievements such as quality and quantity of papers, number and level of books, number and type of patent and so on. Although teaching performance is one of the requirements, but it lacks of rigid execution. From the angle of teachers, teachers' concept and quality are directly reflected on teaching effect, being the main body of the teaching quality. Part of the university teachers focus on their own professional knowledge and constantly in-depth study. But they usually assume that as long as the scientific research and academic achievements are enough, teaching work will be also good, as a result, they lack consciousness of teaching quality and fail to improve their teaching quality.

\subsection{Lack of effective evaluation system}

Researches on scholarship of teaching is still in the early stages, so schools and teachers pay less attention to it, lacking effective evaluation system of scholarship of teaching. At present, most colleges and universities evaluate teachers from two aspects of teaching and scientific research, but the focus is often on the scientific research level. Then the evaluation of teaching become a mere formality, considering the teaching workload only and ignoring evaluation of teaching quality. The existing evaluation system lead to a phenomenon that teachers invest too much energy in scientific research to consider teaching work. They take a perfunctory attitude to 
scholarship of teaching, let alone to sum up the experiences of teaching, innovative teaching methods, or improve teaching quality.

\subsection{Lack of sound motivation and restraint mechanics}

There are two main motivation for teachers to focus on scholarship of teaching: one is the realization of self-worth. They love their teaching career, and hope to benefit students and achieve teaching achievements through their own teaching art. The other is recognition of their outstanding teaching and prize from school. However, the existing teaching management system lack excellent teaching achievement motivation and rigorous punishment on neglecting teaching. This unsound incentive and constraint mechanism causes that teachers concentrate their energy on scientific research, and just complete the teaching work, paying less attention to teaching quality.

\section{Reform strategies of colleges and universities teaching management based on scholarship of teaching}

Based on the problems existing in the teaching management in colleges and universities, combined with the actual situation of our country and foreign mature ways of teaching academic management, several reform strategies of college teaching management are put forward from the perspective of scholarship of teaching, hoping to provide a reference for the development of education in China.

(1)Improving the teaching management idea based on scholarship of teaching

Managers in colleges and universities should clear that teaching is also an important part of academic, and should form teaching management idea from the perspective of scholarship of teaching. First of all, the existing management system should be perfected on the basis of the connotation of scholarship of teaching. And the system unfavorable to improve the teaching quality should be adjusted to balance scientific research and teaching work. Second, teaching academic norm should be made to clear teachers' dos and do nots in scholarship of teaching, further improving the incentive and constraint mechanism. Finally, it is necessary to form atmosphere of scholarship of teaching in the school, which can attache great importance to the teaching for teachers and provide a good environment for improving teaching ability.

(2)Constructing detailed teaching management system based on scholarship of teaching

Teaching management in colleges and universities has the dual function of administrative management and academic management, playing an important role in the higher school management. Detailed teaching management system based on scholarship of teaching is beneficial to improve the level of teaching management in colleges and universities, and ensure the efficient operation of the teaching works. Refinement of the management system is mainly reflected in the following: depositing teaching management contents, focusing on quality management based on the combination of the workload management and quality management; clearing management standards and taking whole process management; establishing and perfecting the mechanism of supervision and inspection, timely feedback problems and implementing corrective actions. Intensification of teaching management system is conducive to timely found the problems, and then we can take systematized management on teaching quality.

(3)Constructing teaching quality evaluation mechanism based on scholarship of teaching

Lack of effective evaluation system as well as the unsound incentive and restraint mechanism are the two main problems existing in teaching management. Therefore, it is necessary to build teaching quality evaluation mechanism based on the academic teaching, which is conducive to mobilize enthusiasm and initiative of teachers' teaching. Then, it is good for innovating teaching methods and improving teaching quality. On the basis of the existing researches and field investigation results, this paper establishes a set of practical teaching quality evaluation index system, and gives the ideal weight of each index(seeing in table 1). These index weight can be slightly adjusted based on each school's actual situation. The index system reflects the concept of teaching and scientific research at the same time, and realizes the integration between the two. In the evaluation process, we should also pay attention to the quantitative evaluation of each index, and combine teaching workload and quality management as well as incentives and punishment.

(4)training teaching team based on scholarship of teaching

Teachers are the disseminators of knowledge, and they are also the direct perpetrators of teaching. Teachers have a close relationship with teaching quality, and it is of great significance to develop teaching team with scholarship of teaching. In order to improve the system of teaching communication and expression, schools can organize regular teaching academic activities. Such kind of activity is convenient for teachers to communicate problems in the teaching process, share experience and learn from others, and it can finally improve the overall teaching level of the contingent of teaching. In addition, in the selection of teachers, school should pay more attention to the teaching ability, and configure knowledge structure of teachers reasonably. And then the excellent teachers' exemplary role can be given full demonstration, and a united, efficient, high quality teaching team will be built.

\section{CONCLUSIONS}

Teaching is the foundation of the school, and teaching quali ty is the vitality of colleges and universities. Reform of teaching management in colleges and universities must stre ngthen the concept of scholarship of teaching, and deepen $t$ 
hemutual penetration and mutual influence between teachin $\mathrm{g}$ and scientific research. And then improving the scientific research level on the basis of teaching attitude improvement and teaching achievement improvement. From the perspect ive of scholarship of teaching,existing problems of colleges and universities teaching management and reform strategy of colleges and universities teaching management based on scholarship of teaching are researched in this paper, which has important practical significance.

Tab. 1: Teaching quality evaluation index system

\begin{tabular}{|c|c|c|}
\hline First class index & Second class indexes & Third class index \\
\hline \multirow{6}{*}{$\begin{array}{l}\text { Teaching attitude } \\
\quad(0.12)\end{array}$} & \multirow{2}{*}{ Principles $(0.4)$} & Teacher's morality $(0.5)$ \\
\hline & & Discipline $(0.5)$ \\
\hline & \multirow{2}{*}{$\begin{array}{l}\text { Sense of responsibility } \\
(0.3)\end{array}$} & Attendance $(0.4)$ \\
\hline & & Students morality guide $(0.6)$ \\
\hline & \multirow{2}{*}{ Initiative $(0.3)$} & Teaching preparation $(0.4)$ \\
\hline & & Teaching/guidance enthusiasm (0.6) \\
\hline \multirow{6}{*}{$\begin{array}{l}\text { Teaching performance } \\
\quad(0.35)\end{array}$} & \multirow{2}{*}{ Teaching quality $(0.6)$} & Classroom teaching assessment $(0.6)$ \\
\hline & & Teaching rewards and punishments $(0.4)$ \\
\hline & \multirow{2}{*}{ Number of tasks $(0.2)$} & Work load of teaching $(0.5)$ \\
\hline & & Students practice guidance $(0.5)$ \\
\hline & \multirow{2}{*}{$\begin{array}{l}\text { Teaching construction } \\
\text { (0.2) }\end{array}$} & Teaching construction situation $(0.4)$ \\
\hline & & Teaching research $(0.6)$ \\
\hline \multirow{9}{*}{$\begin{array}{l}\text { Guidance ability } \\
\quad(0.18)\end{array}$} & \multirow{3}{*}{ Teaching ability $(0.55)$} & Ability of modern teaching methods $(0.4)$ \\
\hline & & Curriculum development and explain ability $(0.3)$ \\
\hline & & Accomplishment of teaching tasks $(0.3)$ \\
\hline & \multirow{3}{*}{$\begin{array}{l}\text { Teaching management } \\
\text { ability }(0.25)\end{array}$} & Understanding and communication skills $(0.4)$ \\
\hline & & Innovation ability $(0.3)$ \\
\hline & & Classroom discipline and atmosphere control ability $(0.3)$ \\
\hline & \multirow{3}{*}{$\begin{array}{l}\text { Cultural quality level } \\
\qquad(0.2)\end{array}$} & Education knowledge accumulation $(0.4)$ \\
\hline & & Professional knowledge attainment $(0.4)$ \\
\hline & & Physical and mental quality $(0.2)$ \\
\hline \multirow{6}{*}{ Scientific work $(0.35)$} & \multirow{2}{*}{$\begin{array}{l}\text { Scientific research project } \\
\text { (0.45) }\end{array}$} & $\begin{array}{l}\text { Number of scientific research project application, } \\
\text { completement }(0.5)\end{array}$ \\
\hline & & Output number of scientific research achievements $(0.5)$ \\
\hline & Papers, writing ( 0.25$)$ & Number and level of academic papers, works (1) \\
\hline & \multirow{2}{*}{$\begin{array}{l}\text { Academic activities } \\
(0.2)\end{array}$} & Academic reward $(0.5)$ \\
\hline & & Academic conference $(0.5)$ \\
\hline & Patent certificate $(0.1)$ & $\begin{array}{l}\text { Patent Applications for inventions, utility models and designs } \\
\text { (1) }\end{array}$ \\
\hline
\end{tabular}

\section{Acknowledgements}

This research is supported by Twelve - Five Planning Project in Educational Science of Jiangsu Province ( Study on the Basic Route of the Construction of
Regional Teachers Development Alliance - - Taking the South of Jiangsu as an Example)

\section{References}

[1] Sun Yanxia. On the Standards of Monitoring Ability of Teaching from the Perspective of Scholarship of Teaching and Learning[J]. Journal of Hebei University, 2012, 37(3):6-8.

[2] Li Heng, ShiQunrong, Chen Xinyan. Research on College Teaching Management Reform from the Perspective of Scholarship of Teaching and Learning[J]. Chian Adult Education, 2014,16:141-142.

[3] Wang Fangliang, Dao Jing. The Reflection and Reconstruction of the Teaching Evaluation System under the Horizon of Scholarship of Teaching and Learning[J]. Heilongjiang Researches on Higer Education, 2012, (8).

[4] Zhao Lei. Strategies of Stabilizing the Team of University Counselors under the Personnel Agency System[J]. Journal of Yangzhou University, 2008,12 (4) :23-27.

[5] Yuan Weixin. Scholarship of Teaching and Learning: A New Perspective of University Teachers' Professional Development[J]. Exploration of Higher Education, 2008 (1): 22-25.

[6] Yao Limin, Ji Shanshan. The Academic Theory of University Teaching $[\mathrm{J}]$. Higher Science Education, 2006 (6): 55-58.

[7] Song Yan. Foreign Research Review on "Scholarship of Teaching and Learning"'[J]. Jiangsu Higher Education, 2010 (2): 67-70.

[8] Yu Yulong. Strengthening Scholarship of Teaching and Prompting Win-win for Teaching and Scientific Research in Colleges and Universities[J]. China Higher Education, 2012 (1): 33-34.

[9] Shi Jinghuan, Xu Tian, Li Yifei. The Current Situation of Teaching Scholarship in China: An Empirical Study of 44 Higher Education Institutions[J]. Journal of Higher Education, 2011, 12: 53. 